$\left(5 \times 10^{-5} \mathrm{Mol}\right)$ und das Glukosid in 60 proz. Äthanol $\left(4 \times 10^{-5} \mathrm{Mol}\right)$ gelöst, wobei der Chlorwasserstoffgehalt der Lösungsmittel zu 0.1 Proz. eingestellt wurde (Fig. 4).

Aus der Kurvenform und Absorption in der Nähe von $358 \mathrm{~m} \mu$, wie in Fig. 4 angegeben ist, kann man darauf schliessen, dass das Tulipa-Aglykon nichts anderes als Delphinidin selbst ist. Noch weiter stimmt Tulipa-Aglykon mit DelphinidinPräparat von K. Hayashi nach papierchromatographischer Methode gut überein.

Zum Schluss möchte ich Herrn Prof. Dr. K. Hayashi in der Tokyo Universität für Erziehung für seine vielseitige Belehrung und stetige Anregung meinen tief gefühlten Dank aussprechen.

\title{
Literaturverzeichnis
}

Hayashi K., Acta Phytochim. $8: 68$ (1934). — Ebenda 9: 25 (1936). Kuroda C. und Wada M., Proc. Imp. Acad.Tokyo $11: 235$ (193̄̄), _— Ebenda 11: 238 (1935). Reynolds, T. M., Robinson R. und Scott-Moncrieff R., Journ. Chem. Soc. London 1934:1235. Robinson G. M. und Robinson R., Biochem. Journ. $25: 1698$ (1931) ; $26: 1657$ (1932). Willstätter R. und Mieg W., Liebig's Ann. Chem. 408: 80 (1915).

\section{A Large Silicified Wood of Aleurites from the Miocene of Isikawa Prefecture, Honsyu*}

\author{
by Shunji WATARI**
}

\section{亘理俊次**：石川県中新世隡のアブラギリ属の化石木*}

Received June 30, 1956

Recently the writer received a fragment of silicified wood, about $7 \times 10 \times 15 \mathrm{~cm}$ in size, together with a set of ground sections from Mr. H. Matsuo of the Geological Institute of the Kanazawa University. According to him the specimen was obtained from a huge trunk more than one meter in largest diameter and at least five meters in length, and he also announced that it was found from a green tuff formation (Miocene) at Seryo, Oosugidani-mura, Nomi District, about thirty Km southwest from Kanazawa City, Isikawa Prefecture.

For precise identification, several additional sections were cut. The state of preservation of internal structures in these sections is found to be fairly poor, inflation, deformation or disorganization of elements being observed elsewhere. However small areas which retain a considerable detail of structures are scattered here and there in most of these sections, and after carefully examining through them the

* Contributions from the Division of Plant-Morphology, Botanical Institute, Faculty of Science, University of Tokyo, N.S. No. 73.

** Botanical Institute, Faculty of Scienca, University of Tokyo. 東京大学理学部植物学教室 

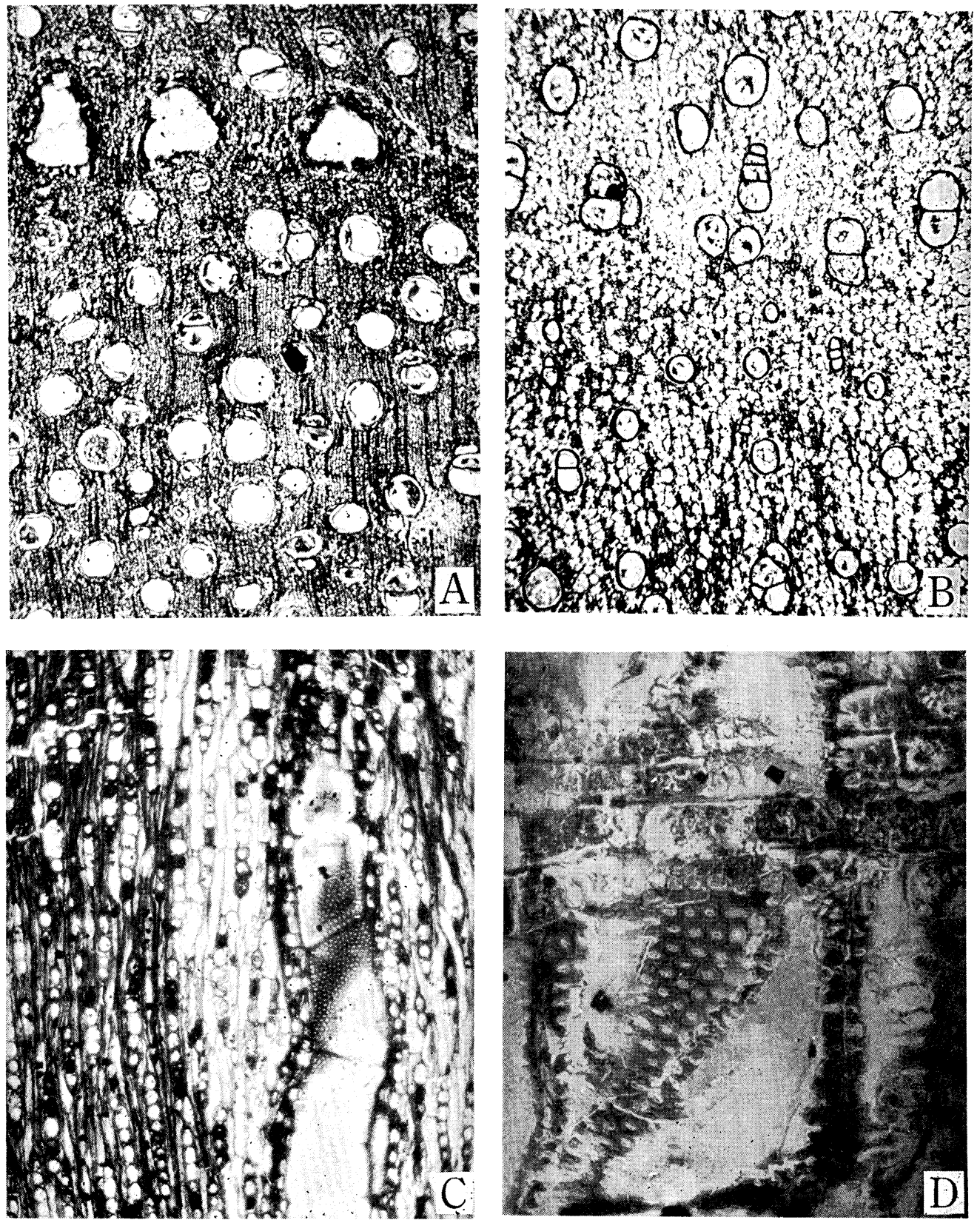

Fig. 1. Aleurites miocenica Watari, sp. nov.

A, cross section of a narrow-ringed specimen; three large triangular lumina on the upper part of the figure are traumatic secretory canals $(\times 20)$. B, cross section of a broad-ringed specimen showing the ring-porosity of the wood $(\times 20)$. C, tangential section showing a vessel and many uniseriate rays $(\times 80)$. D, radial section showing a vessel, a ray, and vasicentric parenchyma ( $\times 300$; cf. Fig. 2). 
writer came to the conclusion that the fossil in hand should be identified as an extinct species of Aleurites (Fam. Euphorbiaceae).

Aleurites miocenica Watari, sp. nov.

Description. Wood apparently ring-porous excepting narrow rings where this feature is more or less obscure (cf. note on p. 471). Boundaries of growth rings distinct but faintly, deliniated by a few layers of slightly flattened elements. Pores predominantly solitary and in radial multiples of 2-3 (occasionally up to several), or rarely in a netlike circular group or more or less irregularly clustered; solitary pores circular or oval in outline, the largest in earlywood 250-350 microns in tangential diameter; walls generally thin excepting the common-walls which are fairly thickened. Length of vessel segments 250-600 microns ; perforation plates exclusively simple with more or less prominent perforation rim and slunting a ta variable angle; intervessel pits essentially alternate, circular to oval, or not infrequently polygonal through crowding; 6-15 microns in horizontal diameter, apertures lenticular to narrow elliptical and more or less horizontally placed, and 2-several inner apertures frequently confluent; thin-walled tyloses present in some vessels. Non-perforate

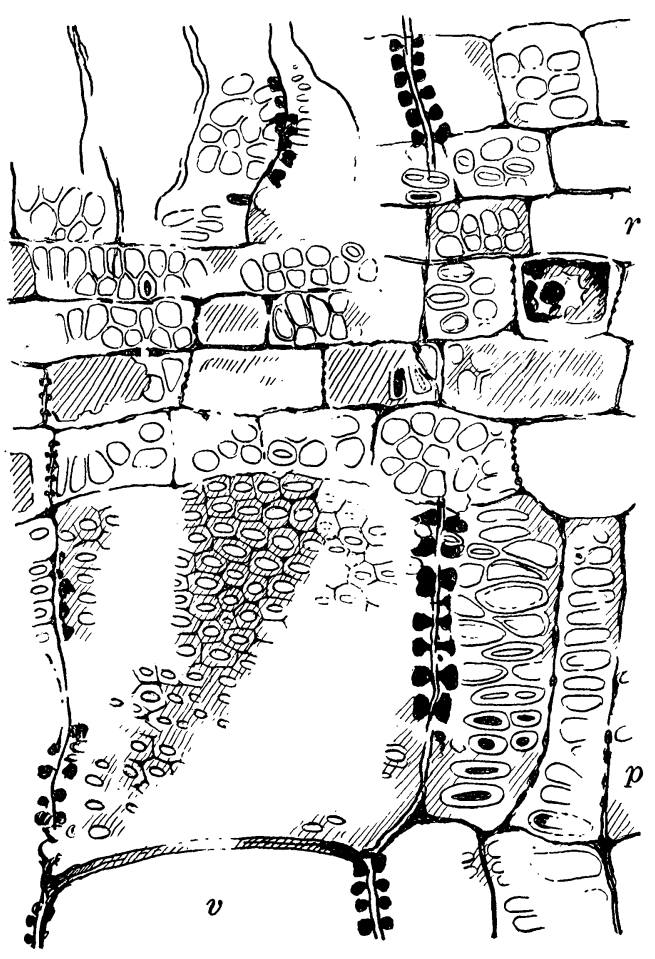

Fig. 2. Aleurites miocenica Watari, sp. nov. Redial section showing a vessel $v$ with crowded polygonal pits, vasicentric parenchyma $p$ with characteristic scalariform pits, and a ray $r$ with various patterns of pits arrangement $(\times 250)$. tracheary elements forming the ground mass exclusively libriform fibers, nonseptate, and arranged in more or less in regular radial rows, mostly 15-30 microns in diameter and very thinwalled. Parenchyma vasicentric and diffuse and slightly more developed in the porous zone; vasicentric parenchyma more or less sheathing the vessel, usually 1-2 layered around smaller pores, whereas in porous zone, occasionally aliform or rarely confluent; diffuse parenchyma scattered solitarily or in small groups among fibers; a parenchyma strand composed of 2several thin-walled elements, individual elements measure 20-40 microns in diameter and 80-150 microns in vertical length; pits into vessel predominantly scalariform, half-bordered and provided with narrow aperture; chambered parenchyma containing figures suggesting the presence of solitary crystal rarely found. Rays unstoried and heterogeneous (Kribs Het. III), uniseriate or rarely 
in part biseriate, $1-20$, mostly $3-10$, cells high, consisting of a series of oval to circular cells, 15-40 microns in tangential diameter and provided with conspicuous triangular intercellular spaces; in radial section, it reveals that rays are composed exclusively of upright and squarish cells or interspersed by a few layers of short procumbent ones which correspond to the isodiametric elements in the tangential section. Excepting the part where a ray passes through the ground mass, upright elements $20-35,40-$ 60 microns, squarish ones, usually $20-40$ microns, and procumbent ones $45-80 \times 15-35$ microns, in radial and vertical diameters respectively, whereas when a ray contacts with larger pores, individual elements more or less radially elongated. All walls slightly thickened and pitted; pits into vessel fairly variable in size, form, as well as in arrangement; circular to oval or angular by mutual contact and arranged in somewhat alternating rows in some places, and then, in other places, elongated or irregularly confuent to form various patterns; more frequently half-bordered with narrow lenticular to elliptical apertures, and occasionally simple. A tangential row of traumatic intercellular canals present in a cross section (No. $53202 \mathrm{~A}$ ); canals circular, oval, or somewhat triangular in outline, 400-700 microns in tangential diameter, and spaced at 300-700 microns, no large pores being found between them; occlusion suggesting gummy substances present in every canals.

Note:- In a cross section (No. 53202 A) whose preservation is fairly excellent, growth rings are generally narrow, mostly $0.2-1 \mathrm{~mm}$ in width and faintly deliniated by a few layers of slightly flattened elements on the outer margin of increments. Most rings contain only a few layer of large pores or occasionally associate with an intermittent row of much smaller pores on the outer margin of increment, in extremely narrow ones there being only a single row of large pores. In other cross sections (No. $53202 \mathrm{D}$ and E) whose preservation is extremely poor, it is observable that there are a few fairly broad rings (upto $5 \mathrm{~mm}$ ) and pores are diminishing their size more or less abruptly toward the outer margin of increments. Thus it is apparent that the wood is essentially ring-porous and that the condition shown in the narrow-ringed specimen is caused by a lack of the typical zone of the latewood.

Locality and horizon: Seryo, Oosugidani-mura, Nomi District, Isikawa Prefecture; green tuff formation (Miocene); collected by H. Matuo in 1955.

Holotype; Botanical Institute, Faculty of Science, University of Tokyo, No. 53202, represented by nine ground sections (A-H).

Affinity. Important anatomical characteristics in the determination of the affinity of the present fossil may be summarized as follows: (1) ring-porosity of the wood ; (2) fairly large, thin-walled pores which are scattered predominantly solitarily or in small multiples provided with more or less thickened common-walls; (3) simple perforation of vessel segments; (4) non-perforate tracheary elements forming the ground mass composed exclusively of non-septate, markedly thin-walled and largelumened libriform fibers which indicates a soft and light nature of wood; (5) occurrence of diffuse and vasicentric parenchyma; (6) predominantly scalariform pits between parenchyma and vessel ; (7) rare occurrence of the chambered parenchyma; (8) rays which are unstoried and exclusively uniseriate or rarely in part biseriate, 
consisting of upright and squarish elements or interspersed by medial short procumbent ones (Kribs Het. III); (9) fairly variable patterns of pitting between ray and vessel; (10) occurrence of a tangential row of traumatic secretory canals.

Woods which are characterized by the occurrence of exclusively of uniseriate rays are known in many species belonging to a considerable number of families. Most of them, however, are easily eliminated by either of the following characteristics of them, that is, the scalariform perforation of the vessel (e.g. Alnus, Hamamelis, Bucklandia, Cleyera), perforation of vessel is simple but pores are markedly numerous or exceedingly small (e.g. Populus, Salix, Zyziphus, Pyrus, many species of Celarastraceae, Aesculus), and such special patterns of the pore distribution as radial, flame-like, or festoon-like arrangement (e.g. Castanea, Castanopsis, Passania, Sideroxylon). Heterogenity of the rays in the fossil further denies the affinity with such woods as Tamarindus, Koelreuteria, and Pometia. Thus there remain relatively a small number of woods whose rays are uniseriate and heterogeneous when one omits those mentioned above, that is, so far as the writer is aware, they are a certain member of the Euphorbiaceae (Mallotus, Sapium and Aleurites), Combretaceae (Terminallia), and Guttiferae (Callophyllum). However, Sapium, Terminallia and Callophllum are apparently distinguishable by their decided diffuseporosity, the latter being also by the presence of broad bands of metatracheal parenchyma.

As is shown above, the predominantly scalariform pits between parenchyma and vessel makes one of the salient characteristics of the present fossil. This fasture was cited by Ogura (1932) in his study on a fossil species of the Euphorbiaceae, Phyllanthinium pseudohobashiraishi, as a feature which is observable only in the Euphorbiaceae and a few others such as Lauraceae, Anacardiaceae, Hamamelidaceae and Sabiaceae. In this regard, Mallotus is also apparently not the case, since in this genus the pits are circular and arranged alternately. It becomes hence obvious that there is none of woods otherwise a certain member of Aleurites which is perfectly identical with the combination of features listed above excepting the occurrence of traumatic secretory canals.

Recently, in his study on a fossil wood from the Tertiary of Sahara, Boureaux (1955) chose the occurrenc of the traumatic secretory canals as an important diagnostic characteristic and successfully arrived at the conclusion that it is an extinct species of the Combretaceae, Terminallioxylon edengense. Such a feature may, indeed, usefully and powerfully be utilized so far as this particular character is combined with an assortment of other characteristics which is common to the specimen under consideration and another fossil or living representative. It should be noticed here, however, that one scarcely expects a constant occurrence of such a sporadic feature in a given specimen as in the case of the present material in which only a single row of the traumatic canals is present among three cross sections, On the other hand, it is to be noted that there exist perhaps a considerable 
number of woods whose possession of this character is unfortunately unrecorded or overlooked. In the present state of the wood anatomy of the dicotyledonous woods, our knowledge concerning to the said character may be somewhat different from case of some coniferous woods such as some members of the Pinaceae and Taxodiaceae whose traumatic reactions have been repeatedly discussed as an important item in considering their phylogeny.

According to Boureaux, this special traumatic reaction occurs in twenty-five families including the Euphorbiaceae and he noted that it is known in this family only in some species of Croton. As mentioned by him, there are no records of the presence of this character in the modern representatives of Aleurites and the writer also fails to find out it in $A$. cordata, yet it is not regarded, as discussed above, as a factor which denies the affinity of the fossil with the said genus, since other numerous characters strongly indicate it, but the occurrence of the character in an intimately allied genus Croton belonging to the same subfamily may rather be capable as a fact intensifying this possibility.

The genus Aleurites comprises of two deciduous species, A. Fordii Hemsl. and A. cordata R. Br., and three evergreen species, A. montana Wils., A. moluccana Willd., and $A$. trisperma Blanco (Pax \& Hoffmann 1931). The pattern of pore distribution in the fossil immediately suggests a close affinity with the deciduous species'). However, the sheath of vasicentric parenchyma, especially in the porous zone, of the fossil is slightly thicker than in the case of modern species. In this connection, it will be appropriate to consider that it is an extinct form of the geuns which is very close either to $A$. cordata or $A$. Fordii.

\section{Ref erences}

Boureaux, E., Bull. Mus. Nat. d'Hist. Nat. 2 sar. 27 (3): 247-255 (1955). Janssonius, H. H., Mikrographie des Holzes der aus Java vorkommenden Baumarten, Bd. 5 (1934). Ogura, Y., Jap. Jour. Bot. 6 (2) : 183-190, pl. IV, tex-figs. 1-4 (1932). Pax, F. \& Hoffmann, K., in Engler \& Prantl's Nat. Pflanzenfam., 2. Aufl. 19 c: 90-100 (1930).

1) Accoding to Janssonius (1934), the wood of A. moluccana is apparently diffuse-porous, pores are scattered very sparsely throughout the increments, and, furthermore, rays are not exclusively uniseriate but they reach $2-3$ cells in width. 